\title{
Damage to spruce stands in the Kysuce and Orava region determined from the National Forest Inventory
}

\author{
V. Šebeň, M. Bošel'a, B. Konôpka
}

Ing. Vladimír Šebeň, PhD., Ing. Michal Bošel'a, PhD., Dr. Ing. Bohdan Konôpka, National Forest Centre, T.G. Masaryka 22, SK-96092 Zvolen, Slovak Republic, e-mail: seben@nlcsk.org, bosela@nlcsk.org, bkonopka@nlcsk.org

Abstract: Šebeň, V., Bošel'a, M., Konôpka, B. 2012: Damage to spruce stands in the Kysuce and Orava region determined from the National Forest Inventory. - Beskydy, 5 (1): 9-18

\begin{abstract}
An analysis of the status of spruce stands in the Kysuce and Orava region was performed and their health condition was compared to the spruce forest constitution in the rest of Slovakia. For this purpose, the inventory plots established within the first circle of National Forest Inventory (NFI) in 2005 and 2006 were used. The Kysuce and Orava regions significantly differ from the rest of Slovak forests by its high proportion of spruce. The health status of the spruce stands in these regions, according to the salvage felling as a result of the damage caused prevailingly by stem rotting and bark beetles appears worse than in the rest of Slovakia. The analysis showed that not only the acute damage of spruce stands (insects) but also the chronic damage of trees (rotting, mechanical damage during logging) is more serious in these regions than in the rest of Slovakia. The browsing caused by deer game (data does not include young stands) in both regions as well as in the rest of Slovakia seems to be low and not so serious compared to the previously mentioned types of damage. Other sorts of damage (stem breakage, standing dead trees, or damage by insect) have also small proportion. More detailed analyses of NFI data with acceptable precision were possible only for most frequent kinds of damages such as stem rotting and damage by logging. The results showed the frequency of rotting tended to be higher with increasing stand age. Influence of altitude on the frequency of the damage was not evident. Since variability of selected types of damage on spruce forest in the target regions was high, all results are presented with the precision at $68 \%$ confidence interval.
\end{abstract}

Keyword: age classes, forest survey, harmful agents, Picea abies, standing stock

\section{Introduction}

Norway spruce (Picea abies [L.] Karst.) is one of commercially most important species in Central Europe. The species is popular in the forestry community because it demands rather easy approaches for management (especially as for silviculture and harvesting) and also in the wood-processing industry thanks to good properties of its stem. On the other hand, the species is relatively sensitive to a variety of stresses (Lindner at el. 2008). Besides other factors, low resistance to abiotic and biotic stress factors is presently related to the occurrence of the species in its suboptimum and/or deterioration of soil conditions (e.g. Spiecker et al. 2004). In Slovakia, Norway spruce is the second most frequent tree species and its stands cover nearly $26 \%$ of the total forest area (Moravčík et al. 2010). On the other hand, Kunca et al. (2011) showed that during the last decade spruce wood made up over $3 / 4$ of the total salvage felling volume. Thus, main attention of forest research should be focused on this tree species. This necessity is related also to knowledge that Norway spruce, especially that grown in lower altitudes, will 
be most endangered by inherent phenomena (mainly drought) of climate change (Mind'áš et al. 2003).

The territories of Kysuce and Orava belong to the Beskids Mountain region. Their areas were highly polluted in 70s and 80s of the last century, thus, some sites are still typical with low $\mathrm{pH}$ of the subsoil (Sitková, Kunca 2008). Most sites, recently covered by spruce stands, are not natural for the species and they were formerly typical with European beech and Silver fir and only occasional admixture of Norway spruce. Thus, the spruce stands in Orava and especially in Kysuce are expected to be more deteriorated than general status of spruce forest on the national level. Konôpka et al. (2010) showed that in the Kysuce and Orava regions forest decline and forest damage had dramatically increasing tendency. These conditions were reflected in huge volume of salvage felling. Thus, for instance, in the northern part of Kysuce volume of salvage felling in the decade of 2000-2009 made up about $1 / 4$ of the standing stock of spruce (Konôpka et al. 2010). The author mentioned high frequency of sparse and fragmented spruce stands with lowered static stability and weakened physiological properties in the region.

In general, harmful agents acting in forests can be categorized as acute and chronic. Acute agents obviously act intensively and in short period, on the other hand, chronic agents less intensively but for long period (often they worsen health status of trees, thus, create favorable conditions for chronic agents; see for instance Stolina et al. 1985). Data related to salvage fellings give relevant information on consequences caused by acute agents (e.g. large destructions by gales or bark beetle outbreaks etc.), but much less knowledge on chronic agents (e.g. mechanical damage by skidding, game browsing, stem rots etc.). The second group of harmful agents may be well recognized and surveyed by terrestrial observations performed on a net of plots spread schematically on a target territory.

Considering all abovementioned facts, we decided to analyze status of spruce stands (including their damage) in Kysuce and Orava as well as on the whole Slovak territory. Further aim of the paper is to compare status of spruce in these regions with general situation on the national level. We used data originating from the Slovak National Forest Inventory which was performed in the years of 2005 and 2006.

\section{Material and Methods}

The data collected within the first circle of National Forest Inventory (NFI) performed in 2005-2006 were used for the study. Altogether 1419 inventory plots (IP) with the area of up to $500 \mathrm{~m}^{2}$ were established in $4 \times 4 \mathrm{~km}$ grid (Figure 1), and broad spectrum of information was

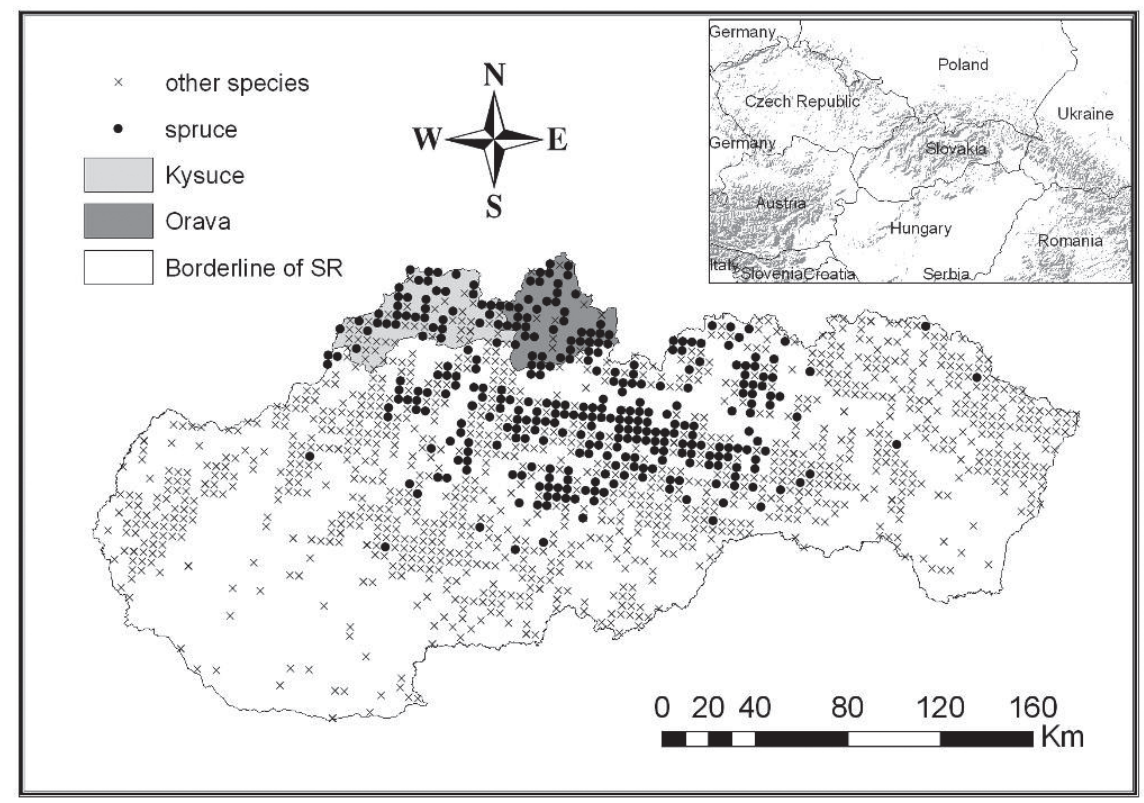

Fig. 1: Localization of inventory plots in the Slovak Republic. The inventory plots with spruce over $50 \%$ are distinguished from the others. 
obtained there (Šmelko et al. 2006). The staticlike data and results obtained of NFI are valid by the end of 2006.

On the each plot, all trees with DBH above $12 \mathrm{~cm}$ were recorder. Trees with diameter at breast height (DBH) between 7 and $12 \mathrm{~cm}$ were measured on a subplot with the radius of $3 \mathrm{~m}$. Each tree on the plot was measured for basic biometric parameters. Moreover, damage caused by different agents such as thinning and cutting (especially during skidding), rotting, game, insect, stem breakages (caused by wind, snow or rime), and others were recorded. Specific harmful factors were detected only by visual assessment of forest survey specialists (they were organised in five inventory groups).

The study was focused on three regions - Kysuce, Orava and the rest of Slovak Republic (SR). For each locality the results were processed by mathematical-statistical procedures specially modified for NFI of SR. Mean value of each variable for each locality and a category is presented. The standard error (at $68 \%$ confidence interval) was calculated according to specific approach (Šmelko et al. 2008), because not only each variable varies but also the plot area varies from plot to plot. Thus, the errors are presented in the figures together with mean values.

For this study, only spruce stands, where spruce had over $50 \%$ of total basal area, were selected. In these plots, the proportion of damaged trees was calculated on the basis of both tree number and stem volume. Differences in total number and volume of damaged trees between selected regions were tested by Student t-test.

\section{Results and discussion}

\section{Basic characteristics of the forest status in Kysuce, Orava, and the rest of Slovakia}

The forest area of Kysuce and Orava makes up less than $10 \%$ from the total forest area of Slovakia (Table 1). However, not only the plots located in forest land (according to forest law) but also the plots established on other land covered by forest and meeting the forest definition that was applied in the NFI (Šmelko 2006). The proportion of forest covering the other wooded land is essentially high, and it is about $20 \%$ of the total forest area in study regions contrary to the rest of Slovakia, where it is less than $15 \%$. The total forest cover here is much higher compared to the rest of Slovakia.

The mean standing volume per hectare in Kysuce region is higher than in the rest of Slovakia. It is the result of the different forest structure, especially by different age structure and species proportion. On the other hand, the standing volume per hectare in the Orava region corresponds to the rest of Slovakia spruce forests.

The species proportion of the Kysuce and Orava region rather differs from the rest of Slovakia (Figure 2). This region is characterized by the dominance of spruce stands planted on sites where mainly fir-beech forest originally grew (Kulla 2010). According to NFI the spruce proportion in the Kysuce and Orava region reaches in average $66.5 \pm 9.3 \%$, while only in Orava region it is more than $80 \%$, and in the Kysuce region it accounts for more than $50 \%$. Beech has still quite high proportion here (in average 13.6 $\pm 3.9 \%$ ), as well as Scots pine has high proportion in the region $(9.5 \pm 3.5 \%)$. Other species together have only $10 \%$. In the rest of Slovakia the spruce proportion is much less $(22.4 \pm 1.6 \%)$, while beech has as much as $31.7 \pm 1.7 \%$. Rather high proportion of oak and hornbeam is characteristic for the rest of Slovakia.

As our main focus was on spruce stands status, we distinguished plots with dominant proportion of spruce from the others. In this sense the stand in each plot was determined by forest type, where the limit was $50 \%$ proportion of particular species using the basal area. Hence, three most represented forest types were distinguished for both Kysuce and Orava region (spruce, pine and beech stands) - overall 104 from 123 IP. For the rest of Slovakia forests we

Tab. 1: Basic characteristics of the target regions in terms of forests (all tree species).

\begin{tabular}{lcccccc}
\hline \multicolumn{1}{c}{ Region } & $\begin{array}{c}\text { Number } \\
\text { of IP }\end{array}$ & $\begin{array}{c}\text { Forest } \\
\text { area }\end{array}$ & $\begin{array}{c}\text { Share to } \\
\text { Slovak forests }\end{array}$ & $\begin{array}{c}\text { Forest } \\
\text { cover }\end{array}$ & \multicolumn{2}{c}{ Growing stock } \\
\hline & {$[\mathrm{pcs}]$} & {$[$ ths.ha] } & {$[\%]$} & {$[\%]$} & {$\left[\mathrm{m}^{3} \cdot \mathrm{ha}^{-1}\right]$} & {$\left[\mathrm{mil}^{\left.-\mathrm{m}^{3}\right]}\right.$} \\
\cline { 2 - 7 } Kysuce (A) & 75 & $113 \pm 13$ & $5.2 \pm 0.6$ & $70 \pm 8$ & $331 \pm 28$ & $37.4 \pm 5.4$ \\
Orava (B) & 48 & $71 \pm 11$ & $3.3 \pm 0.5$ & $46 \pm 7$ & $261 \pm 23$ & $18.6 \pm 3.2$ \\
Beskydy (A+B) & 123 & $185 \pm 17$ & $8.5 \pm 0.8$ & $58 \pm 5$ & $304 \pm 19$ & $56.0 \pm 6.2$ \\
Rest of SR (C) & 1296 & $1990 \pm 26$ & $91.5 \pm 1.2$ & $41 \pm 1$ & $261 \pm 5$ & $518.9 \pm 12.3$ \\
Entire SR (A+B+C) & 1419 & $2174 \pm 22$ & 100 & $44.3 \pm 0.4$ & $264.4 \pm 5.1$ & $574.8 \pm 12.4$ \\
\hline
\end{tabular}




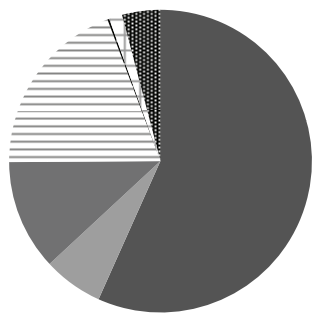

(A)

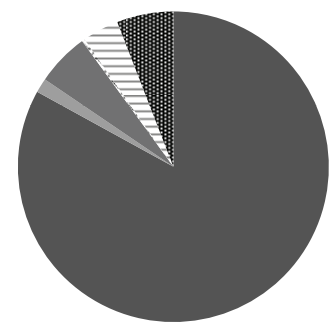

(B)

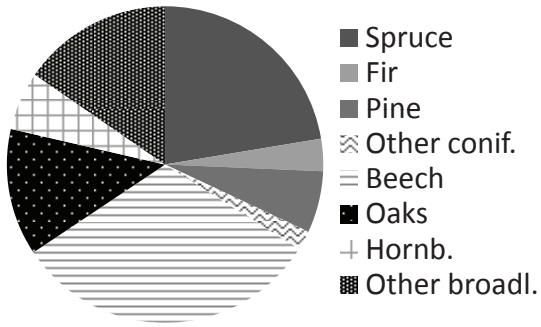

(C)

Fig. 2: Tree species composition in Kysuce (A), Orava (B) and the rest of Slovakia (C).

Tab. 2: Basic characteristics of the target regions in terms of spruce forests.

\begin{tabular}{lccccc}
\hline \multicolumn{1}{c}{ Region } & $\begin{array}{c}\text { Number } \\
\text { of IP }\end{array}$ & $\begin{array}{c}\text { Forest } \\
\text { area }\end{array}$ & $\begin{array}{c}\text { Share to } \\
\text { Slovak } \\
\text { forests }\end{array}$ & Growing stock \\
\hline Kysuce (A) & {$[\mathrm{pcs}]$} & {$[$ ths.ha] } & {$[\%]$} & {$\left[\mathrm{m}^{3} . \mathrm{ha}^{-1}\right]$} & {$\left[\mathrm{mil.m}^{3}\right]$} \\
\cline { 2 - 6 } Orava (B) & 38 & $53 \pm 9$ & $2.4 \pm 0.4$ & $439 \pm 44$ & $23.1 \pm 4.7$ \\
Beskydy (A+B) & 39 & $57 \pm 10$ & $2.6 \pm 0.4$ & $291 \pm 27$ & $16.6 \pm 3.2$ \\
Rest of SR (C) & 252 & $110 \pm 13$ & $5.0 \pm 0.6$ & $362 \pm 27$ & $39.7 \pm 5.5$ \\
Entire SR & 329 & $482 \pm 25$ & $22.1 \pm 1.1$ & $339 \pm 12$ & $163.4 \pm 10.1$ \\
(A+B+C) & & & & & \\
\hline
\end{tabular}

were able to distinguish far more forest types - except of the previous it was also oaks, hornbeam, and others. In the following, we only focused on spruce stands. From the entire NFI database we selected only those plots where the proportion of spruce from basal area was more than $50 \%$.

It is apparent from the table 2 that large part of spruce stands of Slovakia is mainly concentrated in the Kysuce and Orava regions. While the share of the regions from Slovakia area is only $8.5 \%$ the spruce stands in the regions have the proportion more than $20 \%$ from the spruce stands over the Slovakia territory. The mean standing volume per hectare of the spruce stands in the Kysuce is much higher in comparison with the rest of the Slovakia spruce stands. The standing volume per hectare of spruce in the Orava is lower, which can be caused by the higher proportion of the area at high altitudes up to the timber line.

The variation in altitude points out the rather big differences between Kysuce and Orava region (Figure 3). The altitude in Kysuce shows the left-side distribution with large proportion of the altitudes between 500 and $800 \mathrm{~m}$ a.s.l. The altitude in Orava as well as in the rest of Slovakia has rather normal distribution, and the altitude 800 - $900 \mathrm{~m}$ a.s.l. dominates in Orava region (about $40 \%$ of the area). The altitude in the rest part of Slovakia spruce forests has normal distribution with the maximum from 1000 to $1100 \mathrm{~m}$ a.s.l. (20\% of the area).

The age structure of spruce stands in the both regions is rather inhomogeneous (Figure 4). In the Kysuce, the stands of age between 80 and 100 yrs old (fifth age class) with one-third share dominates. It is followed by youngest spruce stands (first age class: 1-20 yrs old) and third age class (41-60 yrs old). The older stands cover rather small area. The age structure of spruce stands over the Orava as well as over the Slovakia show rather normal distribution with the dominance of middle-aged stands (4l-60 yrs old).

\section{Damage to tree stems in spruce stands}

The health status can be defined by various ways (e.g. proportion of salvage felling, amount of dead standing and lying trees, defoliation of trees), however, we chose to estimate it through the occurrence of stem damage (because of available data).

The first round of NFI in Slovakia brings information on actual status of forests (to the end of the year of 2005). Thus it is likely to essentially differ from the status recorded in the official 


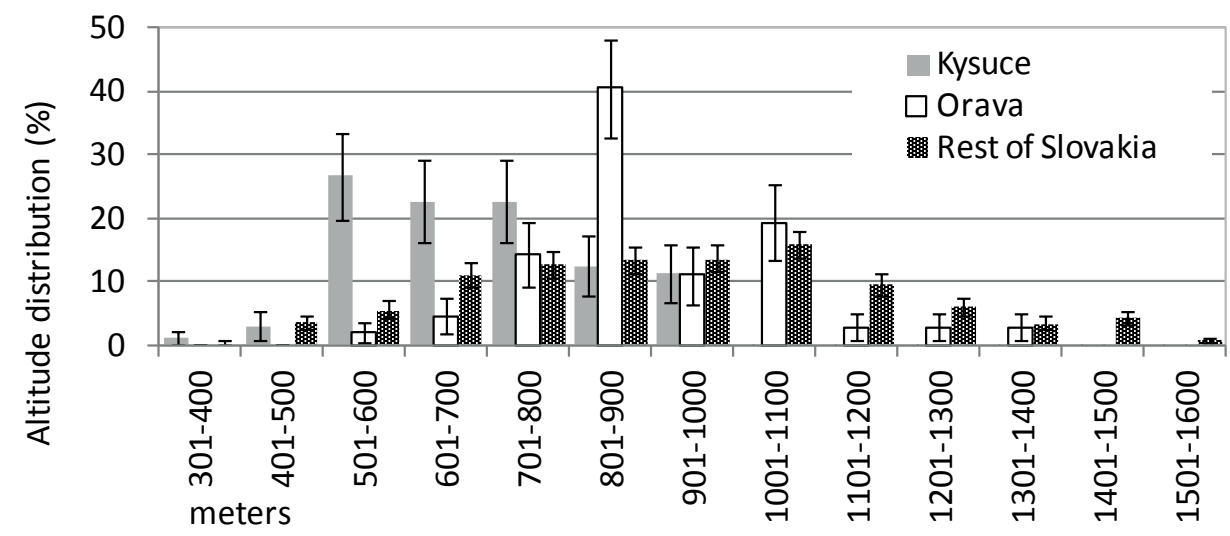

Fig. 3: Altitude distribution of spruce stands in the target regions.

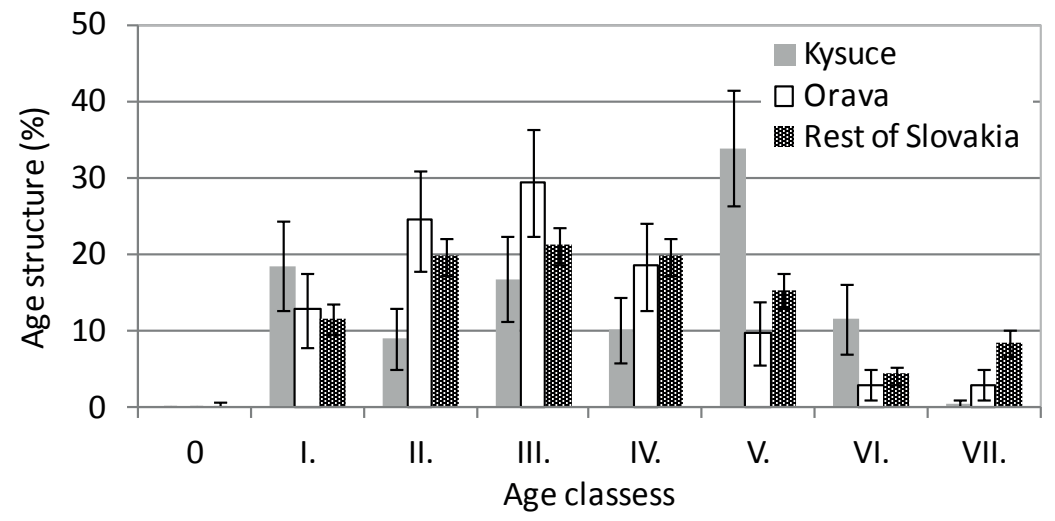

Fig. 4: Age structure (defined by 20 year-age classes) of spruce stands in selected regions.

forest management records (where the salvage felling has being recorded). Sampling-based inventories, which are performed at several-year intervals, do not allow recording damaged trees, which were previously logged. This is mostly evident for acute damages caused by insects. In such cases seems better to use the official forest management records.

The NFI can provide reliable information on chronic damage to forests, of which the symptoms can be easily identified visually. Those kinds of damage are such as damage by games, rotting, crown (stem at crown part of a tree) and tree top breakage, and mechanical damage caused by logging. The acute damage that was followed by salvage logging can be identified by identification of stumps or lying dead wood, however, the reason cannot be inferred at all.

We analyzed the proportion of individual kinds of damage (damage to stems by logging, stem rotting, debarking by deer sp., damage by insects and other types of damage to tree stems).

The proportion of spruce trees damaged by felling is essentially high $(20 \%$ calculated from tree counts, and 30\% when calculated from standing volume; Figure 5). When comparing between the regions, there is no significant difference ( $p>0.05)$.

It was shown that the occurrence of stem rotting is far higher than the damage caused by logging, and it can be considered as the most serious chronic disease in spruce stands (Figure 6). In this type of damage markedly higher regional differences ( $p>0.05$ ) were found. The highest proportion of rotting spruce stems was found in the Orava region ( $60 \%$ from standing volume, or $40 \%$ from tree counts). In the Kysuce region, about 50\% (from standing volume) or one-third (from stem counts) of spruce was damaged by rotting. Spruce in the rest of Slovakia was 


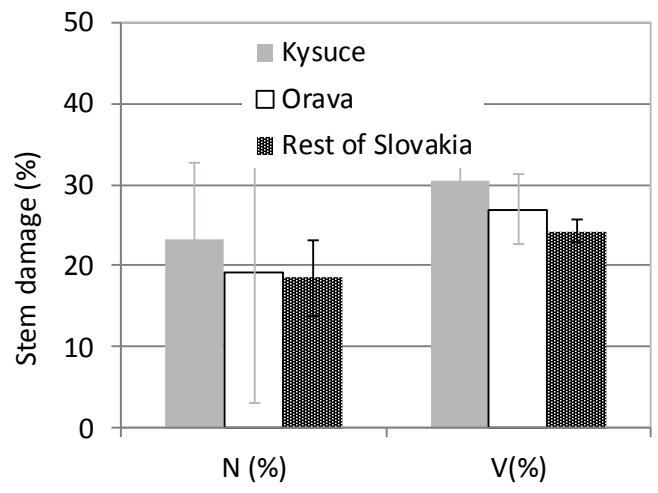

Fig. 5: Damaged stems by felling after NFI, share of tree number $(N \%)$ and tree volume (V\%).

found as less damaged by rotting (less than $40 \%$ from standing volume, or one-fourth from tree counts). The results suggest that mostly older trees are likely to be damaged by rotting (as suggested by the higher proportion of damage when calculated from standing volume).

Rather favourable status of spruce forests was found for damage in form of deer browsing (Figure 7). The proportion of damaged trees is far lower than in the previous cases. In the average the proportion did not exceed $10 \%$, while the higher proportion can be found when calculated from tree counts than from standing volume. It means that the damage by games is concentrated in younger trees (stands). In the Kysuce, the proportion of damaged trees caused by debarking is very small and can be thought as less important. However, it was higher in Orava region or in the rest of Slovakia spruces forests.

The occurrence of stem breakage at crown part of trees is far lower than other damages, and it is similar to browsing (Figure 8). When the

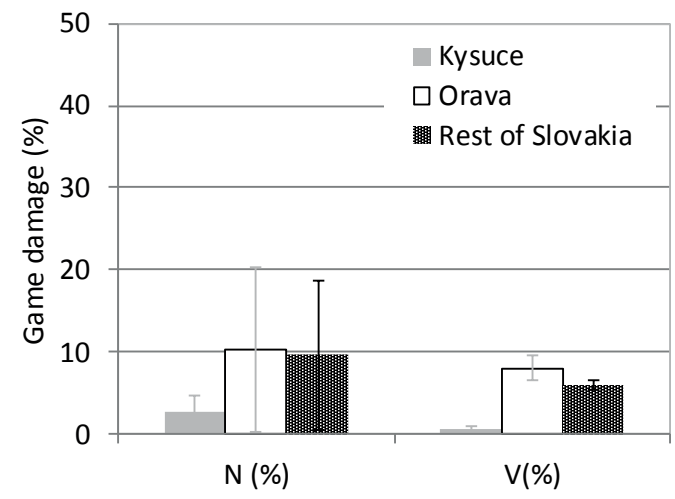

Fig. 7: Game damaged stems after NFI, share of tree number (N\%) and tree volume (V\%).

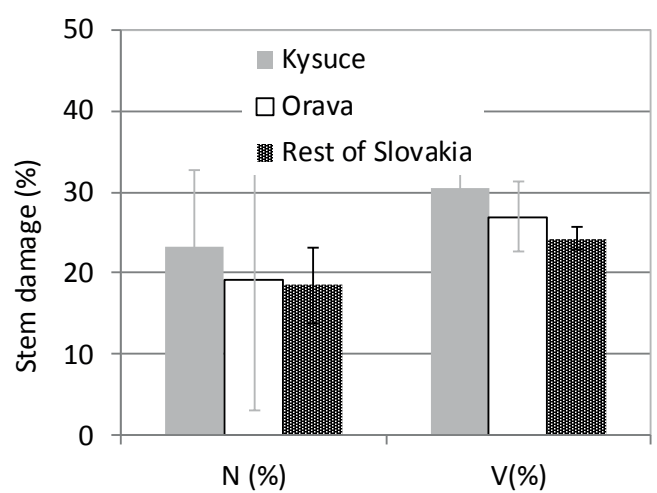

Fig. 6: Rot stems damaged after NFI, share of tree number (N\%) and tree volume ( $V \%)$.

regions are compared, the Kysuce was found as more damaged than the Orava or the rest of Slovakia spruce forests.

\section{Other types of damage to spruce trees}

The occurrence of damage to spruce trees caused by insects was found to be very low. The highest proportion of damaged trees calculated from the standing volume was identified in the Orava region $(4.1 \pm 1.2 \%$, and only $0.7 \pm 6.0 \%$ when calculated from tree counts). In the Kysuce we found lower occurrence of insect infestation than in the rest of Slovakia spruce stands ( $1.4 \pm 0.6 \%$ vs. $2.0 \pm 0.2 \%$, respectively). It is related to acute and short-term character of this type of damage, and the infestation of the tree by insects leads to rapid dying of the tree followed by its removal from the stand by the forester. The NFI is thought to be unsatisfied for recording of this type of damage, and some other methods should be preferred instead (such as forest management records, remote sensing, or others).

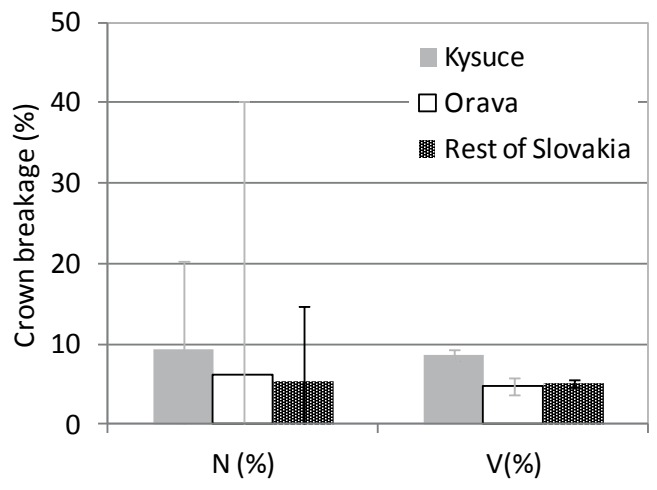

Fig. 8: Crown braked trees after NFI, share of tree number (N\%) and tree volume ( $V \%)$. 
The amount of standing dead trees does not differ between the Orava and Kysuce regions. In the Kysuce, in the average $8.6 \pm 2.2 \mathrm{~m}^{3} \cdot \mathrm{ha}^{-1}$ of standing dead trees was recorded. In the Orava, it was $8.2 \pm 2.9 \mathrm{~m}^{3} \cdot \mathrm{ha}^{-1}$, and in the rest of Slovakia spruce forests amounted to $9.3 \pm 1.39 \mathrm{~m}^{3} \cdot \mathrm{ha}^{-1}$. Even the differences in the proportion of dead standing trees from the living trees between the regions were rather low $(2.0 \pm 0.5 \%$ in the Kysuce, and $2.8 \pm 1.0 \%$ in the Orava). Such low occurrence of standing dead trees in spruce stands can be explained by the intensive and responsible forest management.

We can conclude that the occurrence of other types of damage (breakage of entire stems, icing, snow damage, or damage caused animals) was very low in the NFI.

\section{Analysis of damage to tree stems by logging and rotting}

For more detailed analysis we selected most frequented types of damage in order to bring reliable results. For those types with very small occurrence the standard error of the estimates would have been rather large to make any inferences.

The analysis of the damage caused by logging according to age classes showed the highest proportion of damaged trees in middle-aged stands (60-100 yrs old; Figure 9). No significant differences were found between the regions. Less proportion of damaged trees can be found in young and oldest forest stands. It is related to intensity of the use of logging and transporting techniques.

The occurrence of logging-caused damage within the altitude classes differ between the regions Figure 10).
The damage to tree stems caused by rotting shows apparent relationship with the age of forest stands, where the proportion of damaged trees increases with the age (Figure 11). The most apparent relationship can be seen in the rest of Slovakia spruce forests (except for Kysuce and Orava region), where the proportion of rotting stems increases till fourth age class (61-80 yrs old). The culmination was reached in oldest stands (over 120 yrs old), where the proportion was over $50 \%$. The same trend (but the absolute proportion is higher) is apparent also in the Orava region. Contrary, no such trend can be seen in the Kysuce region; however, the spruce stands in the region are affected by stem rotting more than the others.

The apparent trend can be also found with the altitude in all the study regions (but mostly in the Kysuce) - increase of the proportion of rotting trees with increase in the altitude (Figure 12).

After analysing all our results we approached to comparison them with the outputs from National Forest Inventory in the Czech Republic (http://www.uhul.cz/il/vysledky/). From the recorded damages of tree stems (game, rotting, breakage, and standing dead trees) the highest proportion was found for rotting (19 $\pm 4 \%$ of individuals) and debarking (10 $\pm 2 \%$ of individuals). Low proportion was found for standing dead trees $(3 \pm 1 \%)$, and stem breakage was as much as $6 \pm 1 \%$. In the Moravian-Silesian region the results are as follows: rotting $20 \pm 11 \%$, debarking $19 \pm 11 \%$, stem breakage $4 \pm 4 \%$ and standing dead trees $2 \pm 3 \%$.

On the other hand, our results of field surveying do not fit to the results of salvage felling from the selected region (Konôpka et al. 2010). The amount of salvage loggings in the Kysuce

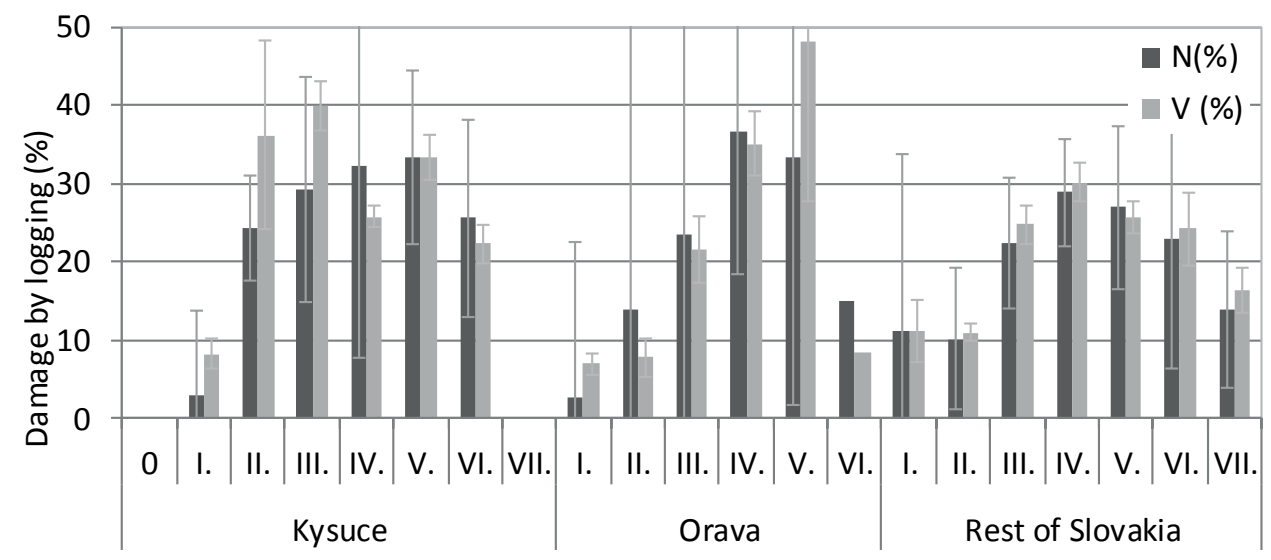

Fig. 9: Damaged stems by logging after NFI by age classes, share of tree number (N\%) and tree volume (V\%). 


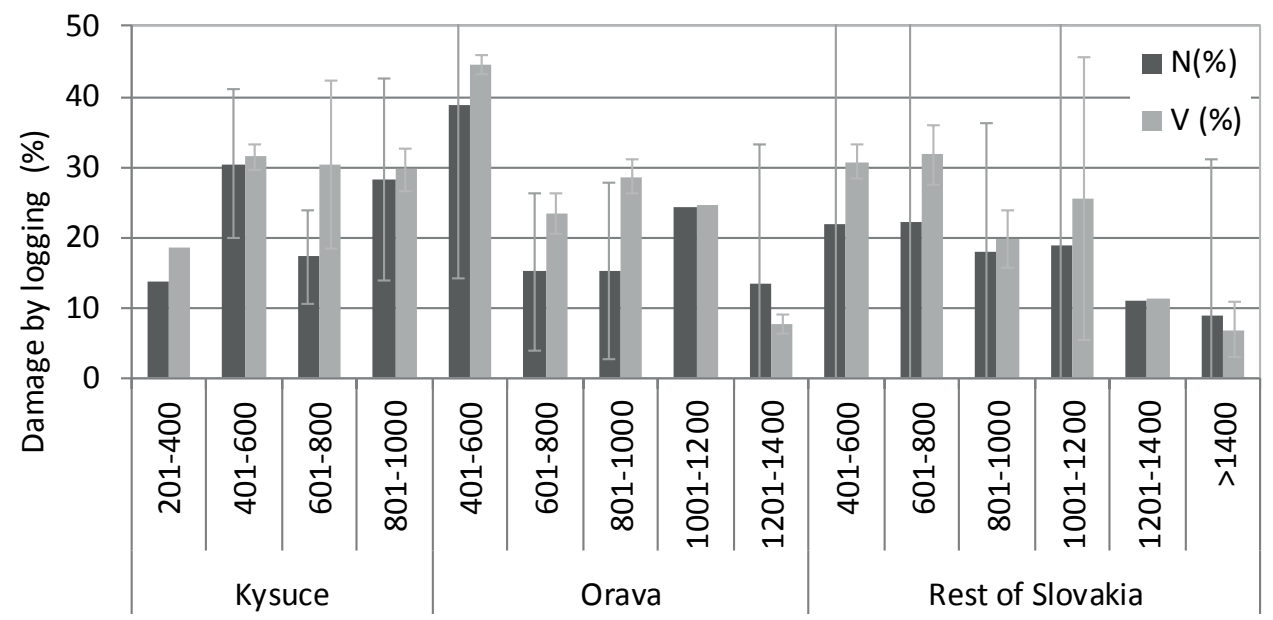

Fig. 10: Damaged stems by felling after NFI by altidude, share of tree number (N\%) and tree volume (V\%).

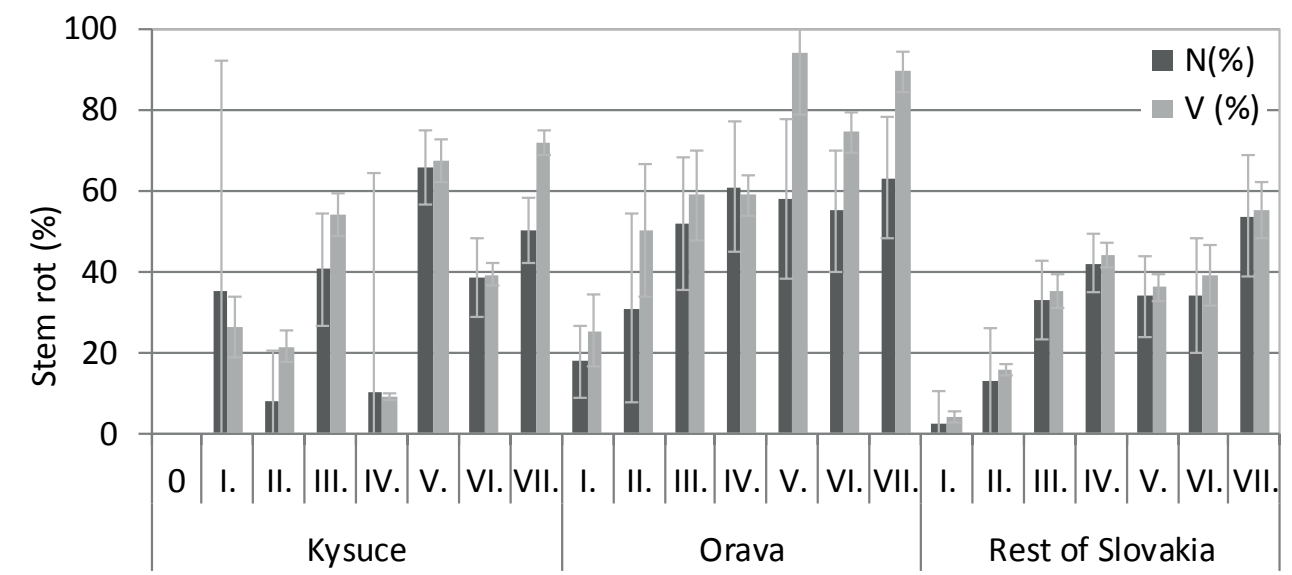

Fig. 11: Stem rot damage after NFI by age classes, share of tree number (N\%) and tree volume (V\%).

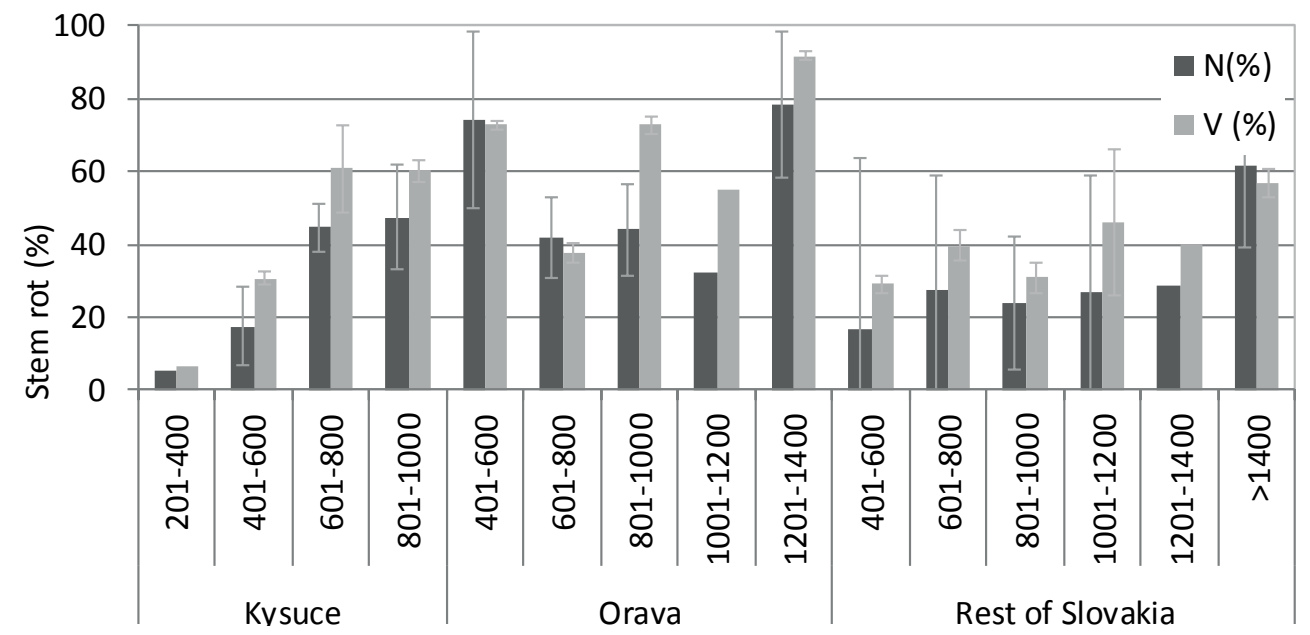

Fig. 12: Stem rot damage after NFI by altidude, share of tree number (N\%) and tree volume (V\%). 
and Orava regions since 2000 till 2009 significantly increased from 238 thsd. $\mathrm{m}^{3}$ up to 1017 thsd. $\mathrm{m}^{3}$, which is more than four-times higher. The highest intra-annual increase was between 2004 and 2005 (the time when the NFI was being performed) - from 564 thsd. $\mathrm{m}^{3}$ to 822 thsd. $\mathrm{m}^{3}$ (as a result of windthrow in 2004). The share of windthrow, or snow damages from the total salvage felling essentially oscillated in this period. The highest proportion of these two agents together was recorded in 2002, when the salvage felling was $56 \%$ from the total salvage loggings. The highest amount of windthrow (51\%) was in 2005.

\section{Conclusion}

Kysuce and Orava are the typical spruce regions, which are recently much damaged by salvage felling, especially due to fungal diseases and bark beetles. In both regions, as according to the official forest evidence, the spruce stands are highly damaged, and we can state that their health status is worse than in the rest of Slovakia.

Health status, however, can be expressed through a long-acting damaging agents on the tree stems that will not cause immediate death (and subsequent removal) of trees. Chronic damage to spruce stems is mainly caused by the logging, game browsing, and stem rotting. The analysis of tree data obtained from the first cycle of NFI in SR (2005-2006) showed that the most important chronic factor is stem rotting,

\section{References}

KonôpKa, B., Kunca, A., Malová, M. 2010: Rozbor podielu mechanicky pôsobiacich abiotických činitel'ov pri hynutí smrečín na Kysuciach a Orave podl'a údajov o náhodných tažbách. [Analyses of contribution of mechanically acting abiotic agents to forest spruce dieback in Kysuce and Orava after records on salvage felling] In: Konôpka, B. (ed): Výskum smrečín destabilizovaných škodlivými činitel'mi. Vedecký recenzovaný zborník, Zvolen: NLC, 239-246.

KuLla, L. 2010: História nepôvodných smrekových lesov v oblasti Kysúc. In: Kulla, L., Sitková, Z. (eds.) Hynutie a rekonštrukcie smrečín na Slovensku [History of non-original spruce forests in region Kysuce] Recenzovaný zborník, NLC - LVÚ Zvolen, 1-14.

KuncA, A. et al., 2011: Occurrence of harmful agents in the Slovak forests in 2010 and their of which proportion is $60 \%$ in Orava region, and over $50 \%$ in Kysuce. These harmful agents are followed by a relatively high proportion of damage caused logging processes with $30 \%$ proportion in the Kysuce, about $25 \%$ in the Orava (less than 20\% in the rest of Slovakia). Game was shown to be little significant harmful factor, and in the Orava it does not exceed $10 \%$ of the total standing volume, and in the Kysuce damage by game it has almost negligible importance. The results showed a clear increasing tendency of rotting with increasing of the altitude, while the relationship with the logging was not so clear. The stem rotting and damage caused by logging processes increased with the stand age.

The results from NFI of SR confirmed worsened health status of spruce stands in the Kysuce and Orava. The status of spruce stands in the target regions was worse than overall situation in the rest of Slovakia. It was also proved that the data from NFI are not suitable for recording the acute damages such as bark beetle infestation. To estimate forest damage caused by most kinds of acute damage is better to use the official forest evidence, where the frequency and the amount of the salvage felling are recorded.

\section{Acknowledgement}

The study was supported through APVV0612-07 and APVV-0268-10 projects awarded by the Slovak Research and Development Agency.

prognosis for the year of 2011. National Forest Centre, Zvolen, 107 pp.

Lindner, M., Garcia-Gonzalo, G., Kolström, M., Green, T., Reguera, R., Maroschek, M., Seidl, R., Lexer, M. J., Netherer, S., Schopf, A., Kremer, A., Delzon, S., Barbati, A., MarChetti, M., Corona, P. 2008: Impacts of Climate Change on European Forests and Options for Adaptation. AGRI-2007-G4-06, Report to the EC Directorate-General for Agriculture and Rural Development, Joensuu, 173 pp.

MoravČí, M. et al. 2010: Report on the status of forestry in the Slovak republic of 2009. Green Report. Ministry of Agriculture and Rural Development of the Slovak Republic, Bratislava, 102 pp.

MinĎÁš, J., ŠKVAREninA, J. (eds.) 2003: Lesy Slovenska a globálne klimatické zmeny [Slovak For- 
ests and Global Climate Change]. EFRA, Zvolen, 128 pp.

SitKovĀ, Z., KunCA, V. 2008: Mapovanie kritických zátaží acidity v lesných ekosystémoch Kysúc a Oravy [Mapping of the acidity critical loads for forest ecosystems in the Kysuce and Orava regions]. Zprávy lesnického výzkити, 53 (2): 147-160.

Spiecker, H., Hansen, J., Klimo, E., Skovsgaard, J. P., Sterba, H., von Teuffel, K. 2004: Norway Spruce Conversion - Options and Consequences. European Forest Institute Research Reports, 18, 269 pp.
Stolina, M. 1985: Ochrana lesa [Forest Protection]. Príroda, Bratislava, $480 \mathrm{~s}$.

Šmelko, Š., Merganič, J., Šebeñ, V., Raši, R. JanKovič, J. 2006: Národná inventarizácia a monitoring lesov Slovenskej republiky 20052006. Metodika terénneho zberu údajov, [National forest inventory and monitoring of the Slovak republic 2005-2006. Field Survey Methodics ]NLC Zvolen, $130 \mathrm{~s}$.

Šmelko, Š., Šebeñ, V., Bošela, M., Merganič, J., JANKOVIČ, J. 2008: National forest inventory and monitoring of the Slovak republic 2005-2006. Basic concept and selected summary information. National Forest Centre, 16 pp. 